《解 説》

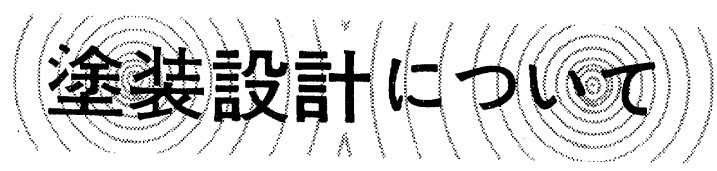

\section{小川陸 夫}

\section{1. 塗装設計とは}

塗装の目的は言うまでもなく, 商品化の最 終段階に执いて，塗料を叙ることによって， その墑品をより美しく，より耐久性のあるも のとして, 每るいは防火, 耐熱, 耐薬品性な どの特殊性能を与兄て, その商品価值を上げ ることである.したがって, 塗装設計とは塗

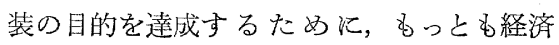
的, 工業的に仕上げるための, 叙装のしくみ をデザインすることであって, 単涂料を選 んで慗るだけでなく，素材の表面調整，処 理から下塗り, 中塗り, 上塗りなどの各種の 塗料を塗り，その間乾かし，研摩などの作業 をくり返して㙦装系として仕上げるための， 表面処理から仕上げまでの材料, 手段, 方 法, 工程の組久合わせをデザインすることで 㘯る，塗装の設計飞当たっては，まず，その 商品, たと光ば自動車, 洗濯機, 什器とか, 船舶, 橋梁など塗る対象品汇よって, その塗 装目的比かっった品質, 性状の塗装材料（塗 料, 表面処理剂なぞ）を選定し, その材料, 商品に適した叙装手段, 万法を検討し，それ らを組多合わせて，もっとも效果的な塗装工 程を選定する。ご和らの組み合わせは抄互い に関連があり,それぞれの関連に沶いて, 塗装 を設計することである。とく最近は, 塗料 之塗装の関係は塗料听塗装とか, 塗装 苛っての塗料, といった車の両輸のような型
で進歩して拉り,たとえば電着塗装しかり,粉 体塗装またしかり,さらに電子線硬化法, 紫 外線硬化法なども塗料あって, 塗装機器設備 があって活用できるものであり，それぞれ切 り離しては塗装でさない。このよう考光る と塗装設計も日進月歩して行くものであっ て，1960年代の塗装では1970年代の塗装は論 ぜられず，今後の塗装設計は，現状をふるえ て，創造的のものでなければならない，その 意味から具体的塗装設計瑐に， $2 \sim 3$ の事象をとらえて, 諭じてみたい。

\section{1-1 塗装設計と塗装品質}

塗装の設計に当たってはまず，その塗装の 目的はどこにあるべきか，ポイントは何であ るか，明らかとして预かねばならない。目 的，目標がなけ机ば，また，それが具体的で なければ塗装設計は組み立てられない，先に も述へたと抒り，塗装の目的は，その商品価 值を上げること,すなわち, 技客が求める商品 の塗装汇対する期待品質を予測し, 実現する ことである、しかるに，怙客が期待する品質 は固定的なものでなく,生活環境, 様式の推移 につれて，その期待品質も流動的に移り変わ るものであり, 今日のように, 住宅産業の発 展, モータリゼーションの普及, さらに都市 への人口集密といったような社会情勢下に招 いては, 当然これらを背景として, 商品のプ レハブ化, 叙膜機能への高度の要求となって 表われて拾り，他方，産業界飞和いても，貿 
易の自由化を前提にして，企業の近代化，合 理化が着々進められていて, 高度のマスプロ 生産方式への移行などからコストに見合った 塗装品質が期待されている。 また，長大橋， 超高層ビル，超大型タンカーなどといった鉄 鋼構造物の巨大化は，補修狳装の困難さから 当然ながら叙装のメンテナンスフリーといっ たような, 高度の耐食, 耐久性をもった塗装 品質が要求されることになり, 杂た, 石油コ ンビナート，鉄鍋団地といった産業都术の出 現は, 大気污染による公害問題とともに, 長 期防食的な鉒装品質が期待されている。 しか しながら一方では, 塗装品質の高度要求とは ららはらに，塗装コスト面では切り下げの傾 问にあって，塗装設計に当たってはコストと のバランスに扔いて，塗装品質を設定せ祇ば ならないのが現状である.

技客が必要とする真の塗装品質は，必ずし もすべてに括いて，完全な，かつすぐれた塗 膜性能を兼ね備光たるのであればよいという ことではなくて，その商品の使用目的，用途 に応じて，それに適合した塗膜性能を具備し ていることが肝要である，したがって，最終 ユーザーがどのような塗装品質を期待し望え でいるか，商品に関する品質情報を集め, 解 析して，はっきりは握ず゙きである、それに よってその期待され望李れる塗装品質をいか にして商品の塗装に具備させるか，亦なわら どのような塗装工程，叙装仕上げによって完 成させるべきか，塗装品質を設計時に予測し なければならない、すなわら塗装設計は塗装 品筫の設定が第一義であるといっても過言で はない。

\section{1-2 㓌装設計と塗装の自動化}

叙装の目的を達成するための塗装設計であ れば当然, 塗装商品の質, 量, コストを考慮 に入れなければならない。とくに最近の塗装 業界の一般状況は, 塗装作業者の不定, 塗装 コストの引き下げ，さらに加えて生産性の问
上といった問題をかかえている現沿からかん がみ，その合理化対策の一つとして，塗装の 自動化が，塗装工程の各部門汇括いて検討が 加兄られつつ㐫る。すなわち自動㓌装機, 静 電叙装機, 自動研摩機などの機械化された塗 装機器をラインに採用することによって， ま た，人手作業を口ボット化して，滁装にさいし て直接人手によらないで, 機械的操作によっ て，自動的塗装仕上げをして，生産速度を 上げ，品質の均一化，人手省力化して人件 費, 工数を低減し, さらに塗料使用量も節約 して，総合コストを低減することが検討さ れ，笑施されつつある。

この事実は今後の塗装設計に当たっては, その塗装省力化の方向から考学ても, 塗装の 自動化をいか注すべかを塗装設計にもり込 まねばならない、しかしながら，だからとい って何でも自動化すればよいということでな

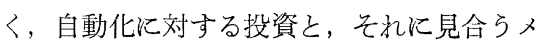
リットが数值的に，十分事前注は握されるこ とが重要であって，いわゆる投資効率をつか んで計画に移さねね゙ならない，それがため， 自動化推進に先立って, 工場の立地条件, 敷 地面積, 使用塗料, 工程, 塗装製品の仕上が り状態, 計画生産の見通し, 資金などについ てよく検封，考慮を払わなければならな

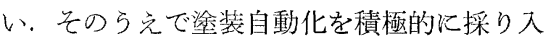
れ，塗装設計することである.

\section{1-3 塗装設計と新塗装技術}

前述の電着塗装法, 粉体塗装法や電子線硬 化法, 紫外線硬化法などといった最近の新し い塗装技術は今後の叙料と叙装の方向性を瞕 示するものと思われる. 今日までの塗装の進 歩は, 琴用塗料を対像として, 塗装機器, 㬁 装手段が検討され，改良されてきたものであ ったが，これらの新しい銰装技術は，塗料の 新技術の開発と, その応用面での塗装法の開 発といった点でおるむきを異にしているもの である、たとえば電着塗装法は, 水溶性樹脂 


\section{4}

塗料の開発によって, 直流電圧を以って塗装 下能な方法が見出され，粉体塗装法は粉体塗 料の開発に上り，その応用面で静電粉体塗装 法，流動浸セキ塗装法などが開発されたもの である.したがって，これらの塗装法による 塗装効果は, 新しい塗料と塗装が両方相まっ て，従来の塗装法を一新するような効果が発 揮するものである. 電子線, 紫外線硬化法は それらの硬化エネルギーの発生源の開発と， それによる硬化樹脂類の開発によって，出現 したものである・したがって，これらの塗装 技術は塗料，塗装，設備なぞがそれぞれ組み 合わされて塗装が可能であり，切り離しては 塗装はできないすなおち一つの塗装システ ムとして考光称ばならない，従来の塗装設計 の手順からすれば，塗料を選定し，それに見 合引塗装手段を決め，叙装工程を組み合わせ ることによって塗装設計されたものである が，これらの塗装技術を活用するに当たって は, 当然, 従来の考方方を捨てて, 新しい観 点に立って設計飞和り込まな计孔ば效果を発 揮しない。

\section{1-4 塗装設計と公害問題}

最近のわが国の経済成長は誠に目ざましい もので少るが，反面そのヒズミから生をれた 公害問題が各企業間で大きな課題となってい る. とくに大企業の化学工業においては, 近 代化とともに公害に対し万善の対策がとられ ている現状である，有機合成化学の製品であ る塗料も当然ながら，工場排水汪るる水質污 濁, 塗料の廃衰物処理飞関する公害の発生の 恐れがあって業界も自主的浲品の検討, 生 産工程の再検討など公害発生源の追求と，そ の防止対策に，さら飞一歩進めて公害防止設 備の開発に鋭意努力している. もちろん塗料 を使用する立場の蒤装企業に打いても，言う

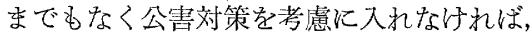
その企業は今後なり立たないことは，事明の 事実である・とくに近年の塗装は，表面処理
皮膜工程を導入することで, 塗装効果が倍加 することから，一般的標準仕様にまでなって きて抢り, そのう光水溶性樹脂塗料, 粉体塗 料などる開発されて，技術が進歩する反面， 水質污濁, 粉ジン公害などの問題を助長する 結果ともなりかねない現状である。したがっ て, 塗料性能がすぐれているからとか, 鋈装 が完全であるから，省力化に通ずるからとい って, 安易に新しい塗料, 塗装工程を組み入 れることはかえって予期せぬ障害に逢着す る、しかしながら，今後の塗装設計は，その 商品汶対しもっとも合理的な塗装仕上げがで きる組久合わせを考光るべきものであれば， 公害対策に対しても積極的姿勢をるって，ぞ のような塗料を，どのような塗装方法，工 程をもって, 工数, 材料費を節約して效果的 な塗装にするかが設計のキーポイントであ る. 単汇生産性，コスト低減にのみ心を痛的 ることなく，公害に対して万善の配慮がとら れるよらな塗装設計を組み立てねばならない し，さもなければせっかくの塗装設計も実施 の段階になって役にたたないものになってし まう。それに整料メーカーなり, 塗装設備

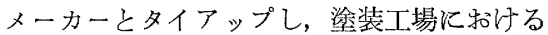
公害発生源の内容を明らかにして和く必要が ある(第 1 表).

\section{2. 塗装設計の進め方}

これからの塗装の設計に当たって考慮すべ き基本的問題についての筆者の所信を前述し たが,実地に設計に入るにさいしては，何を第 一次の条件としてすべさかといらことになれ ば,まず, 被叙装物である商品品質の決定であ ろう。この設定された塗装品質を中心とし て, 塗装設計は展開されて行くべきものであ る.ここでいら塗装製質とは, 広義你解し て,質,量, コストの 3 大要素を指するので,質 とは塗装製品の材質, 型状を含めて, その材 質に対しての塗装仕上げ効果, すなわち塗膜 
第 1 表 塗料中の成 分

\begin{tabular}{|c|c|c|}
\hline 料 & 塗 料 成 & 脂 \\
\hline アルキド樹脂塗料 & $\begin{array}{l}\text { アルキド樹脂 } \\
\text { キジロールルールー } \\
\text { ネラルスピリットなど }\end{array}$ & 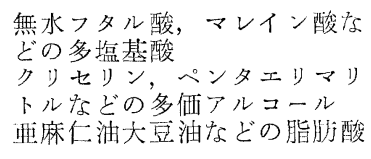 \\
\hline アミノアルキド樹脂漥料 & $\begin{array}{l}\text { メラミン樹脂 } \\
\text { アルキド樹脂 } \\
\text { キシロールルール，ナ } \\
\text { フサブタノール }\end{array}$ & $\begin{array}{l}\text { ^ラミン覀素, ベンゾグアナ } \\
\text { ミン } \\
\text { ホルマリン, ブタノール, メ } \\
\text { タノールなど } \\
\text { その他前項に同じ }\end{array}$ \\
\hline 塩化ビニル樹脂塗料 & 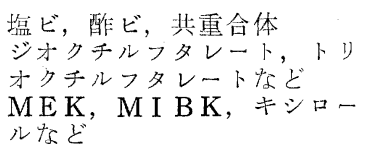 & 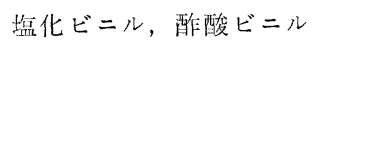 \\
\hline 熱硬化型アクリル樹脂 & $\begin{array}{l}\text { アクリル樹脂, メタアクリル } \\
\text { 樹脂の共重合体 } \\
\text { アミノ樹脂, エボキシ樹脂 } \\
\text { スチレンなど } \\
\text { MI B K, 酢酸エステル } \\
\text { アルコール, キシール, ト } \\
\text { ルオールなど }\end{array}$ & アクリル酸, メタアクリル酸 \\
\hline エポキシ樹脂塗料 & $\begin{array}{l}\text { エポキシ樹脂 } \\
\text { アミノ樹脂 } \\
\text { フェノール樹脂 } \\
\text { アルキド樹脂 } \\
\text { MI B K, 酢酸エステル } \\
\text { キシロール, トルオールなど }\end{array}$ & $\begin{array}{l}\text { エピクロールヒドリン, ビス } \\
\text { フェノールA }\end{array}$ \\
\hline ポルウレタン樹脂塗料 & 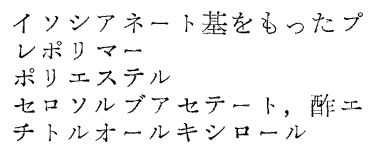 & $\begin{array}{l}\text { トリイソシアネート } \\
\text { ポリエマチルポリオール } \\
\text { ヒマシ油 }\end{array}$ \\
\hline シリコーン樹脂塗料 & $\begin{array}{l}\text { シリコーン樹脂 } \\
\text { アルキド樹脂 } \\
\text { アミノ樹脂 } \\
\text { アクリル樹脂 } \\
\text { MI B K, キシロール, トル } \\
\text { オール }\end{array}$ & $\begin{array}{l}\text { オルガノポリシロキサン } \\
\text { メチルトリクロロシラン }\end{array}$ \\
\hline 塩ビゾル塗料 & $\begin{array}{l}\text { 塩化ビ } \\
\text { D O P }\end{array}$ & \\
\hline 水溶性樹脂塗料 & $\begin{array}{l}\text { アミノアルキド樹脂系 } \\
\text { フェノールアルキト樹脂系 } \\
\text { アミノアクリル樹脂系 } \\
\text { アンモニア, アミン, } \\
\text { 水 }\end{array}$ & \\
\hline
\end{tabular}

次ページヘつづく 


\begin{tabular}{|c|c|c|}
\hline \multirow[t]{7}{*}{ 各色エナメル } & 白系顔料 & チタン白, 雨鉛華, リトポン \\
\hline & 赤系顔料 & $\begin{array}{l}\text { カドミレッド, ベンガラ } \\
\text { トルイジンレッド，キナクリ } \\
\text { ドンレッド }\end{array}$ \\
\hline & 黄色系顔料 & $\begin{array}{l}\text { 黄鉛, チタン黄, オキ+イド } \\
\text { エロー } \\
\text { ベンジンェロー, アントシキ } \\
\text { ンェロー }\end{array}$ \\
\hline & 青系顔料 & $\begin{array}{l}\text { コン青, 群青 } \\
\text { フタロシアニ゙ルー }\end{array}$ \\
\hline & 緑系顔料 & 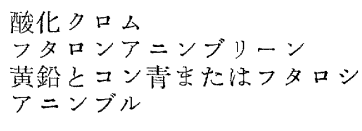 \\
\hline & 黑系顏料 & カーボンブラック, 鉄黑 \\
\hline & 茶褐系顔料 & $\begin{array}{l}\text { 紫ベンガラ } \\
\text { マルーン }\end{array}$ \\
\hline サビ止メ塗料 & サビ止メ顔料 & $\begin{array}{l}\text { 鉛丹, ジンク口 } \\
\text { ジナミド鉛, 塩基性 } \\
\text { 硫酸鉛, 亜鉛末 }\end{array}$ \\
\hline
\end{tabular}

性状, 性能であり, 量とは塗装製品の当面の生 産量,さらに商品のモデルチェンジ, 企業拡大 によりその量的增加を，どの時点にどれだけ 見込むか，将来の見通しを含めた生産桩大予 定量と, それらの質, 量化見合ったコストで める、これらの要素はいずれも相関性があっ て, 生産性, 経済性, 市場性の面加見て, 鈢装設計の側に立って決定されるべき重要な ポイントである，従来ややもするとその塗装 品質が，塗装とは単に塗る作業であるといっ た単純な感覚に打いて，商品設計部門に执い て決定され，塗装の生産性を無視，あるいは それに近い品質が決定されがらである。それ がため，塗装設訴にしわ寄せられ，ムリな， ムダな設計となってさ程を組むことになり， 关㗢に当たって思わ奴トラブル，障堇に突き 当たり塗装作業の中断, あるいは一部の設計 変更を余儀なくされる事態をしばしば見受け ることである.

\section{2-1 塗装材料の選定}

塗装塗膜の性能, 性状は, 塗膜を形成する 過程に打いて, 使用された塗装材料, 前処理 剂や塗料によるところが多い，換言すれば， 塗装品質を作り込むためにはどのような前処 理剂, 塗料を用いて, どのように処理し, 塗 装仕上げするかといらことに帰依する。塗装 品質が決められ，その品質を具現するための 設計の第一歩は, いかなる前処理剂, 塗料を 選ぶかといらことになる。もらろんすぐれた 性能の塗料前処理剂を選んだからといって, 必ずしもよい塗装品質が作り达まれるすので なく, 材料に塗装方法, 工程などの関連にお いて適切な前処理剂, 塗料を選定しなければ ならない.では，塗料の選定の基準を何にお くべきか.

第 2 表 (A)(B) に示すと括り，塗料はその用 途, 目的, 性状, 性能, 塗装法などによって 分類されるものであり，これらの分類からわ かるように塗料はその仕様によって適材適所 
第 2 表 (A)

\begin{tabular}{|c|c|}
\hline 分 & 称 \\
\hline 展色剤による分類 & $\begin{array}{l}\text { 油性叙料, 緎維素誘導体塗料, 合成樹脂塗料, レキ青 } \\
\text { 覧塗料など }\end{array}$ \\
\hline 塗料の状態による分類 & $\begin{array}{l}\text { 堅練ペイント, 淍合ペイント, エマルション塗料, 粉 } \\
\text { 体塗料など }\end{array}$ \\
\hline 塗料の性状による分類 & 速乾性塗料, 熱可塑型塗料, 熱硬化型塗料など \\
\hline 淕膜の性能による分類 & 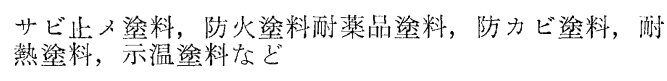 \\
\hline 塗膜の性状による分類 & $\begin{array}{l}\text { ッヤ消シ塗料, 透明塗料らりめん塗料, メタリック塗 } \\
\text { 料, スチップル塗料など }\end{array}$ \\
\hline 塗り方による分類 & 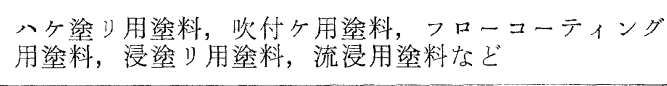 \\
\hline 被塗物に上る分類 & $\begin{array}{l}\text { 整金属用塗料, 自動車用塗料, 船舶用塗料, サッシ用 } \\
\text { 塗料, ガン具用塗料など }\end{array}$ \\
\hline 塗装系による分類 & $\begin{array}{l}\text { ワンコート用塗料, 下, 中, 上塗り塗料, バテ, プラ } \\
\text { イマー, シーラーなど }\end{array}$ \\
\hline
\end{tabular}

第2 表 (B) 各種合成樹脂叙料之性能

\begin{tabular}{|c|c|c|}
\hline 名 & 塗 膜 性 能 & 乾 燥 機 \\
\hline アルキド樹脂塗料 & 付着性, 耐油性, 耐候性 & $\begin{array}{l}\text { 自然 (揮発, 酸化) } \\
\text { 焼付ヶ(揮発, 酸化, 重合) }\end{array}$ \\
\hline $\begin{array}{l}\text { スチレン化アルキド樹脂 } \\
\text { 塗料 }\end{array}$ & 速乾性，酎候性，低温硬化 & $\begin{array}{l}\text { 自然（揮発，酸化） } \\
\text { 焼村ケ(揮発, 酸化, 重合) }\end{array}$ \\
\hline アミノアキルド樹脂塗料| & 耐油性，耐候性，罊硬質 & 焼付ヶ(揮発, 縮合, 重合) \\
\hline 塩化ビニル樹脂塗料 & $\begin{array}{l}\text { 速乾性, 酒的アルカル性, 難燃性, 俬 } \\
\text { 薬品性 }\end{array}$ & 自然（揮発） \\
\hline 塩化ゴム塗料 & 速乾性，酎薬品性，難燃性 & 自然（揮発） \\
\hline 蓺硬化型アクリル樹脂塗 & $\begin{array}{l}\text { 耐候性，耐污染性，不変色，硬質， } \\
\text { 光沢 }\end{array}$ & 焼付ヶ(揮発, 縮合, 重合) \\
\hline 熱可塑型アクリル樹脂湦 & 速乾性, 耐候性, 透明性: & 白然（揮発） \\
\hline エボキシ樹脂塗料 & $\begin{array}{l}\text { 付着性, 酎薬品性, 電気絶縁性, 酎 } \\
\text { 熱性硬踲 }\end{array}$ & 焼付ケ(揮発, 維合, 重合) \\
\hline 二液性エポキシ樹脂塗料 & 酎薬品性, 耐摩耗性, 厚膜 & 自然（重合） \\
\hline $\begin{array}{l}\text { オイルフリーポリエステ } \\
\text { ル塗料 }\end{array}$ & 耐候性, 仃卜ウ性, 不変色, 硬筫 & 烧付ヶ(揮発, 縮合, 重合) \\
\hline
\end{tabular}




\begin{tabular}{|c|c|c|}
\hline ポリウレタン樹脂塗料 & $\begin{array}{l}\text { 耐候性，耐嘛耗性，付着性，硬質， } \\
\text { 觕薬品性 }\end{array}$ & 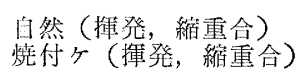 \\
\hline シリコーン樹脂塗料 & $\begin{array}{l}\text { 酎候性, 酎薬品性, 酎熱性, 電気絶 } \\
\text { 縁性 }\end{array}$ & 椥付ヶ（揮発, 縮重合) \\
\hline フッ素樹脂塗料 & 耐侯性, 耐摩耗性, 耐熱性 & 燒付ケ（揮発, 重合） \\
\hline 水溶性樹脂塗料 & 水溶化された樹脂による & \\
\hline 粉体塗料 & 粉体化された樹脂による & 加熟 (溶融, 泠却) \\
\hline 壏ビゾル塗料 & 耐候性, 耐薬品性, 可下ウ性 & 焼付少（重合） \\
\hline
\end{tabular}

のものが設計, 商品化されていて, 単に少品 種で多種多様の用途に適合する性質のもので はない, したがって, 塗装の質, 量, コスト の品質面加ら，塗料と告の造皮膜性，塗膜性 能などを検討し, 被塗物の材質, 塗装目的, 塗装製品の使用場所などの要求に合致した塗 料を選定することが肝要である.さらに最近 塗装工場の公害問題がらんぬんされている垁 状から考觉ると，単俰塗装品質のみを主体と しな設計では実状にはそぐわなく，公害対策 を考慮した塗装設計の観点に立って塗料を選 定せねばならない.

\section{2-2 塗装工程の決定}

生産工程によってその商品の品質が作り达 まれると同様に，塗装品質も塗装工程によっ
て作り込まれるものである・換言すれば，塗 装工程が塗装品質を左右するといっても過言 ではない.したがって，塗料の選定もさるこ とながら，それを用いての塗装工程の決定も 塗装設計の重要なかぎ゙岁る。塗装品質に見 合った適切な塗料を用いても，塗装工程の設 計を䛊れば，しばしば塗装生産の中断，ひい ては量的生産ができない、コストアップにな るなどといった不具合点を招来し，塗装設計 の再検討を余儀なくされる、塗装工程を設計 し決定するにはいか炕すべきか。すず被塗装 物の材質はなんであるか，材質いかんによっ てたと衤ばナシ地鋼板，摩鋼板，表面処理鋼 板, 鋳物, 亜鉛引鋼板,アルミ材などによって, 工程, 回数が変わってくるぬた，その表面状

\section{第 3 表}

\begin{tabular}{|c|c|c|}
\hline 別 & 品 質 要 求 & 適 \\
\hline 1 コート仕上げ工程 & 軽度の防セイ耐久性 & $\begin{array}{l}\text { 什器類, 玩具, 事務用品など } \\
\text { 農機具, カラー鉄板, 針金など }\end{array}$ \\
\hline 2 コート仕上げ工程 & 防セイ性耐久性 & 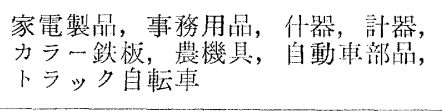 \\
\hline $\begin{array}{l}2 \text { コート } 1 \text { ベーク仕上げ } \\
\text { 工程 }\end{array}$ & $\begin{array}{l}\text { 中程度の防セイ性耐久 } \\
\text { 性 }\end{array}$ & $\begin{array}{l}\text { 家電製品, 事務用品, 什器, 計器, } \\
\text { 農機具, 白動車部品, トラックなど }\end{array}$ \\
\hline 3 ニート仕上げ工程 & 美感, 耐久性 & $\begin{array}{l}\text { 乗用車, 軽 } 4,3 \text { 輪, トラック, } \\
\text { 二輪車, 作機械など }\end{array}$ \\
\hline $\begin{array}{l}4 \text { コート以上の仕上げ } \\
\text { 工程 }\end{array}$ & $\begin{array}{l}\text { 防セイ性, 美感, 酎久 } \\
\text { 性 }\end{array}$ & $\begin{array}{l}\text { 乗用車, 車両, 船舶, 橋梁, 鉄鋼構 } \\
\text { 造物, バスを゙ }\end{array}$ \\
\hline
\end{tabular}


態, 表面のアラサ，サビの状態などにより， さらに塗装仕上り品質である外観的要求度 $(1,2,3$ 級仕上げ）によっても工程が当然 異なってくるべきである，これらの要因を勘 案して塗装工程は設計される。

塗装工程を塗装回数から類別すると，

第 3 表のと扮りになる。

また，塗装工程を機能的に類別し，その面 から被塗装物にどのような工程を採り入れ設 計すべきか，それぞれの互換性，適性を考克 組み立てることになる。

i ）下塗り工程 プライマー工程，木たはサ ビ止メ工程と称せられる工程で, 被塗装物の 慗装系としての防セイ性, 付着性をとくに強 調される工程である。それがため，下叙り用 塗料として適用されるものは，これらの性能 に执いてよりすぐれた塗料が望ましいが，被 塗装物の材質, 型状, 数量, 塗装回数, 塗装目 的などにより取拾選沢し，とくに防セイ性に すぐれたるの，西るいは付着性にすぐれたる の，むたは畭燥性にすぐれたものを，その状 況に応じて選定し，塗装工程を決めていく. 一般に，滁料としては表面処理プライマー， 電着プライマー, ジンクロ, 鉛丹などの防七 イ叙料や，アルキド樹脂，アミノアルキド樹 脂およびラッカー系など各種の展色刘により 分類された塗料がある。

ii）中塗り工程 下塗り工程と上塗り工程の 中間塗装工程であって，その性能はそれぞれ 上下塗リ工程との付着性の向上, ひいては塗 装系としての叙膜耐久性を增大させるととも に表面の山凸を調整して，上塗り工程に括け るッヤ，平滑さなどの仕上りの外観をよりよ くするるのである. 中塗り工程用塗料とし て，とくに仕上りの凹凸の調整を目的とした パテ類，叙膜の耐久性を主眼とした中叙塗 料, プライマーサーフェーサーや，外観のッ ヤ，平滑さの調整用として用いられるグラン ドコートなどがあるが，これらはそれぞれ被
塗装物の状態いかんや，工程の組み方いかん により選択して決定さ礼るるのである.

iii）上塗り工程 塗装系として最終工程であ って, 上塗リ工程のいかんによって, 塗装仕 上り, とくにッヤ, 平滑さ, 塗色の耐久性な ぞの諸性能が左右される. 一般に, 塗装製品 の性能品質はその仕上り塗膜をるって評価さ れるため上鋈リ工程がもっとも重視されがち である。さきにも言及したと拈り，塗装製品 としての評価はあくまで塗装系としての総合 鋈膜の性能品質として評価すべきであって, 単に上塗り工程のいかんのみでは十分ではな いが，その寄与率から考光ると，耐候性，耐 水性, 耐久性, 外観などいずれの諸性能も上 塗り工程の役割は大きい，したがって，塗料 の選定,塗装工程の設定に当たっては,十分検 討すべきである・上塗リ下程用塗料としては 別表に示したと抒り，各種の展色剂（合成樹 脂類）の性能，被叙装物，その材質により， 各種各様の塗料があり，その目的に応じた稌 料を選沢して上塗り工程を決める.

iv）乾燥丁程 塗料を塗装によって被塗装物 飞薄膜とした場合，先の值後に㨟いては，流 動性の状態（ゾル状態）にあるが，時間の経 過，父の他の方法（加熱，冷却など）に上

\section{第 4 表}

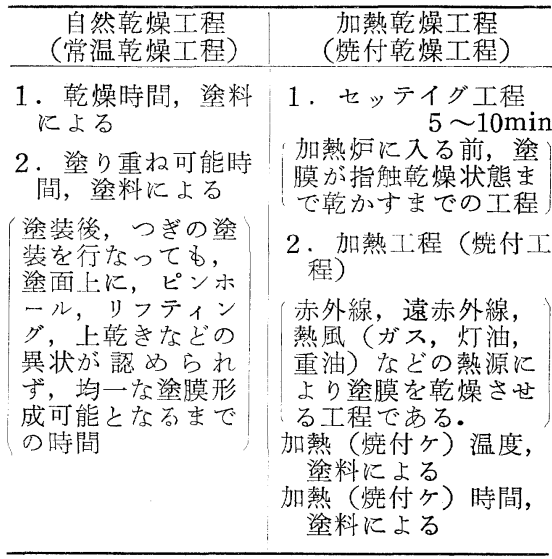


り，流動性がなくなり，固化状態(ダル状 態）の薄膜に変移する。この状態を“塗膜は 乾燥した”と呼称し，塗膜を固化させる工程 を乾燥工程という，塗装工程に护染膜の 乾燥はただ単に乾燥されるだけでは十分でな く，その塗膜表面状態に何らか異状があって は乾燥の目的を達したとは言いがたい。それ がため，その雓料に応じた乾燥工程を設定す ることが重要である。また，被塗装物の型 状, 大きさ, 塗装数量などについて子考慮に 入れ工程を決める (第 4 表).

v）ウェット・オン・ウェット塗装工程
一般に塗装工程は下塗り，中塗リ，上塗り なぞの各塗料を一回塗装して，乾㰒してから つざの塗料を塗装，乾燥して塗り重礼ていく 工程を踏さが, 被塗装物の型状, 大ささ, 数量, 塗装要求品質の度合などにより，1回ごとに 乾燥工程を入れることなく，追いか浽塗りし て，すなわち 2 回塗装して，一度に加熱乾燥 する工程をウェットオンウェットまたは 2 コート1ベーク塗装工程と称する.この工程 を組み入れるためには塗料の種類，塗料の希 橎調整，塗装技能などについてもよく検討し なければよりよい効果は期待できない。

第 5 表

\begin{tabular}{|c|c|c|}
\hline 塗 料 手 段 & 特 & 製 \\
\hline ハケ塗リ & $\begin{array}{l}\text { ハヶを用いて淕るため機械的塗 } \\
\text { 装のできないるに適する, た } \\
\text { だし熟練を要す }\end{array}$ & $\begin{array}{l}\text { 鉄塔, 鉄橋, 船舶, 鉄鋼構造物 } \\
\text { なと }\end{array}$ \\
\hline 浸せキ塗り & 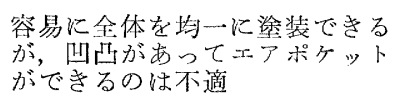 & $\begin{array}{l}\text { シャ一シ，ホイル，自動車下回 } \\
\text { リ，小物部品，ボソベ }\end{array}$ \\
\hline $\begin{array}{l}\text { ロール塗リ } \\
(\text { リバース, ダイレ } \\
\text { クトーール) }\end{array}$ & $\begin{array}{l}\text { 均一な膜厚に高速の塗装ができ } \\
\text { る }\end{array}$ & $\begin{array}{l}\text { 冷延鋼板，要鉊引鉄板，アルミ } \\
\text { 板などの平板 }\end{array}$ \\
\hline $\begin{array}{l}\text { フローューチング塗 } \\
\text { り }\end{array}$ & 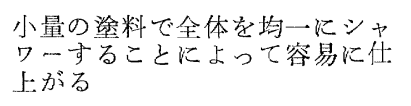 & $\begin{array}{l}\text { 変压器, シャーシ, 自動車部品 } \\
\text { など }\end{array}$ \\
\hline コロガシ雓リ & $\begin{array}{l}\text { 小物製品を多数一度に全体的に } \\
\text { 叙ることができる }\end{array}$ & $\begin{array}{l}\text { 命なメ，ボタン，クギ，小物部 } \\
\text { 品など }\end{array}$ \\
\hline エアスプレー & 多用途向 & 一般金属製全体 \\
\hline エアレススプレー & $\begin{array}{l}\text { 塗料の損失が少なく厚膜が得ら } \\
\text { れる }\end{array}$ & $\begin{array}{l}\text { 軽重車両, バス, 什器, 被塗装 } \\
\text { 物の内部 }\end{array}$ \\
\hline 静電塗装 & $\begin{array}{l}\text { 塗料の損失が少なく連続塗装が } \\
\text { できッキマワリかよい }\end{array}$ & $\begin{array}{l}\text { 家電製品, 什器, 事務用品, 二 } \\
\text { 輸軽重両, 農機具它の他 }\end{array}$ \\
\hline 電着塗装 & $\begin{array}{l}\text { 引火性が少なく, 命わせ目, ッキ } \\
\text { マワリ性がよく均一膜厚の仕上 } \\
\text { げが得られる }\end{array}$ & $\begin{array}{l}\text { 自動車ボディ, 什器, 電気製品, } \\
\text { 部品など }\end{array}$ \\
\hline 粉体流動浸七キ & $\begin{array}{l}\text { 浸七キ塗リ之同様の塗装効果が } \\
\text { 女り愿膜が得られる }\end{array}$ & $\begin{array}{l}\text { ヘンス, 金網, 小物部品, 鉄骨 } \\
\text { ガードレール, 什器など }\end{array}$ \\
\hline 粉体静電塗装 & $\begin{array}{l}\text { 静電塗装々同様の塗装效果があ } \\
り, \text { 愿膜が得られる }\end{array}$ & $\begin{array}{l}\text { ヘンス, 電気部品, 什器, ボン } \\
\text { ベ, 小物部品など }\end{array}$ \\
\hline
\end{tabular}


組み合わせ

1.プライマーとサーフェーサーとの組み合 わせ

2.下塗リと中塗リとの組み合わせ

3. 中塗りと上塗りとの組み合わせ

4. プライマーサーフェーサーと上塗りとの 組み合わせ

5.上塗りと上塗リとの組み合わせ などが考它られる。

vi）研削工程

塗膜の凹凸（素地の状態, オレンジピー ル, キズなど), チリ，ゴミやピンホールな どをサンドペーパー，スチールウール，ト石 などにより研削して平滑にする丁程である。

1. からトギ工程 $\$ 80$ ， \#120，\#180，卜不 などで乾燥状態のままでそぎ落とす工程

2 . 水トギT程 $\$ 240, \$ 320$, $\$ 400$, 耐水ペ 一パ，その他の研削用具をるって，涂膜
表面を水でぬらしながら研削する工程

3. 油トギ工程 ガソリントギ工程とも称す るもので，\#320，\#400サンドペーパーで塗 膜表面をガソリン油で欢らしながら研削す る工程

これらの3つの工程は塗料の種類, 仕上り 要求度合により選定されるるので，とくにか らトギの場合は，やや西るとトギ目が付く ため, 比較的軽度な研削を行なら. 水トギに よる表面研削はトギ目も少なくて，均一，平 滑な塗面が得られるため, 高級仕上げが可能 となる反面, この研削後, 水洗工程, 水切り 乾燥工程（約 $120^{\circ} \mathrm{C}$ で $10 \mathrm{~min}$ 加熱）を挿入す ることとなって多下程となるたる, 塗装丁程 としては複雑となる・油トギは研削後ガソリ ンふき工程のみとなり，水卜ギ目程と比べ て, 作業性の点で問題はあるが，比較的工程 も少なくてすみ，仕上げる良好である。ただ

\section{第 6 表}

\begin{tabular}{|c|c|c|c|c|c|c|c|c|c|c|c|c|c|c|c|c|}
\hline 塗装手段 & $\begin{array}{l}\text { 油 } \\
\text { 性 } \\
ヘ ゚ \\
ィ \\
ン \\
\text { ト }\end{array}$ & $\begin{array}{l}ア \\
ル \\
\neq \\
ト ゙ \\
\text { 樹 } \\
\text { 脂 } \\
\text { 塗 } \\
\text { 料 }\end{array}$ & $\begin{array}{l}\text { 硝 } \\
\text { 化 } \\
\text { 綿 } \\
\text { 塗 } \\
\text { 料 }\end{array}$ & 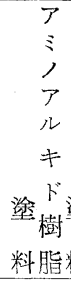 & $\begin{array}{l}\text { 熱 } \\
\text { 硬 } \\
\text { 华 } \\
\text { 型 } \\
\text { 了 } \\
\text { y } \\
\text { y } \\
\text { 涂ル } \\
\text { 樹 } \\
\text { 料脂 }\end{array}$ & 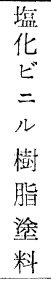 & $\begin{array}{l}x \\
\text { ポ } \\
\neq \\
\text { キ } \\
\text { 樹 } \\
\text { 脂 } \\
\text { 塗 } \\
\text { 料 }\end{array}$ & $\begin{array}{l}\text { プ } \\
\text { ラ } \\
\text { ス } \\
\text { チ } \\
\text { ゾ } \\
\text { ル } \\
\text { 型 } \\
\text { 塗 } \\
\text { 料 }\end{array}$ & $\begin{array}{c}\text { 不 } \\
\text { 飽 } \\
\text { 和 } \\
\text { ポ } \\
\text { リ } \\
\text { 樹工 } \\
\text { 脂天 } \\
\text { 塗テ } \\
\text { 料ル }\end{array}$ & $\begin{array}{l}\text { メ } \\
\text { 夕 } \\
\text { ए } \\
ッ \\
\text { y }\end{array}$ & $\begin{array}{l}\text { 八 } \\
\text { ン } \\
\checkmark \\
1 \\
1 \\
\text { ン } \\
\text { 叙 } \\
\text { 料 }\end{array}$ & 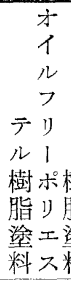 & 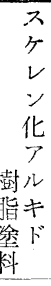 & $\begin{array}{c}\text { シ } \\
\text { 1) } \\
z \\
1 \\
\text { y } \\
\text { 樹 } \\
\text { 脂 } \\
\text { 塗 } \\
\text { 料 }\end{array}$ & $\begin{array}{l}\text { 水 } \\
\text { 溶 } \\
\text { 性 } \\
\text { 樹 } \\
\text { 脂 } \\
\text { 叙 } \\
\text { 料 }\end{array}$ & $\begin{array}{l}\text { 体 } \\
\text { 塗 }\end{array}$ \\
\hline ハケ塗り法 & (a) & 0 & $x$ & $\otimes$ & $x$ & $\otimes$ & $\otimes$ & $x$ & (a) & $x$ & $x$ & $x$ & $x$ & $x$ & $\otimes$ & $x$ \\
\hline エアスプレー法 & O & (a) & (a) & (a) & (a) & (a) & (C) & (a) & (C) & (a) & (a) & (C) & (C) & (C) & $\otimes$ & $x$ \\
\hline エアレススプレー法 & 0 & (a) & (a) & (a) & (a) & (C) & (a) & $x$ & $x$ & $x$ & $x$ & (C) & $\otimes$ & $x$ & $x$ & $x$ \\
\hline 静·電塗装法 & $x$ & 0 & $\otimes$ & (C) & (C) & $\otimes$ & $\bigcirc$ & $x$ & x & $\otimes$ & $x$ & $\otimes$ & (C) & $x$ & $x$ & $x$ \\
\hline フローコーチング法 & $x$ & 0 & $\times$ & 0 & $\times$ & $\times$ & $\times$ & $x$ & $\times$ & $x$ & $x$ & $\otimes$ & $x$ & x & O & $x$ \\
\hline カーテンコーチング法 & $x$ & $x$ & O & $x$ & $\times$ & $\otimes$ & $x$ & $\otimes$ & (C) & $x$ & $x$ & $x$ & $\times$ & $x$ & $x$ & $\times$ \\
\hline 浸セキ塗リ法 & $\stackrel{\times}{\times}$ & O & $x$ & O & $\times$ & $x$ & $x$ & 0 & $x$ & $x$ & $x$ & $x$ & $x$ & $x$ & (a) & $x$ \\
\hline ロールコーチング法 & (9) & $x$ & $x$ & 0 & (a) & 0 & 0 & 0 & $x$ & 0 & $x$ & 0 & $x$ & $\bigcirc$ & $x$ & $x$ \\
\hline 電着塗装法 & $x$ & $x$ & $x$ & $x$ & $x$ & $\times$ & $x$ & $x$ & $\times$ & $x$ & $x$ & $\times$ & $\times$ & $x$ & (a) & $\times$ \\
\hline 粉体静電塗装法 & $x$ & $x$ & $x$ & $x$ & $x$ & $\times$ & $x$ & $x$ & $x$ & $\times$ & $x$ & $x$ & $x$ & $\times$ & $x$ & (a) \\
\hline " 流動漫セキ法 & $x$ & $x$ & $x$ & $x$ & $\times$ & $\times$ & $x$ & $\times$ & $\times$ & $\times$ & $\times$ & $\times$ & $\times$ & $x$ & $x$ & (2) \\
\hline 紫外線硬化法 & $x$ & $x$ & $x$ & $x$ & $\times$ & $\times$ & $x$ & $\times$ & (C) & $x$ & $\times$ & $x$ & $x$ & $\times$ & $x$ & $\times$ \\
\hline
\end{tabular}

注) ( ) 良好 $\bigcirc$ 可能 $\otimes$ 可能性がある $\times$ 不可能 


\section{2}

し，ガソリンを使用するための多少の困難と 安全衛生面での対策が必要となる。生しろ， 水トギのできない被塗装物，たとえば木材仕 上げには好適である。

\section{2-3 塗装手段の決定}

塗料が選定され，塗装工程が決められたな らば，それらの塗料を用いて，工程別によ゙の ような塗装機器を用いて塗装するかを決める ことになる.ここでいら塗装手段とは塗装機 器を用いて塗装する方法を示するので，単層 の造皮膜手段を指す。塗装手段はハケ塗リか ら最近の電着凃装まで，塗装の技術革新によ り各種あって，それらの塗装手段はどのよう な塗料でも，どのような被塗装物でも適用で きるといらものではなく，それぞれ適不適が ある、したがって，塗装手段に対する適性を 考慮して決定しなければならない。たと兄 ば, 被塗装物の種類, 型状, 大きさ, 材質, あるいは油性, 水性, 粉体, 無溶剂性といっ た塗料の種類によって，また，下塗り，中塗 リ，上塗リ丁程によって適切な塗装手段を設 定する。

i) 被塗装物と塗装手段

被塗装対象製品とそれに適した塗装手段と の関連性を表にすれば（第５表）のと和りで ある・

ii）塗料と塗装手段

塗装中の展色剂, 溶剤の種類とか, 塗料物 性, たとえば，顔料容積濃度，粘チュウ度， 分散状態，極性などによって，それぞれ塗料 に適した塗装手段がある（第 6 表）.

\section{むすび}

塗装設計はいかにあるべきかについて，筆 者なり塗装設計の意義を考察し，その手順 について記述してきたが，今日まで長い間，

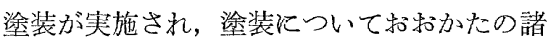
先輩が発表されておられるが，塗装設計の意 義に関するものについては，いま一つ物足り ないものがあり，今回，本誌をかりて，筆者 の塗装経験から塗装設計はどのよらにあるべ きか，束た，初歩的な塗装設計の進め方につ いてほとらてみたものであるが，これを契機 として体系化された塗装設計が組み立てられ れば，まことに幸甚である，単に，塗料を塗 るにはどのような塗装方法によればよいとい らことでなく，素材から表面処理塗装仕上げ に至る工程に抹いて，塗装材料，表面処理設 備, 塗装機器, 設備, その取り扱い方法, 塗 装工程の組み合わせなど一連の体系化して塗 装シムテムを確立しなければならないのでは ないか。最近, 各産業界に批いては, 商品の耐 用期間に関する機能保証を商品メリット，セ ールスポイントとして打ら出していく傾向に あり，こ扎関連して，当然，塗装業界に打 いても塗膜保証の型で，信頼性を打ら出して いくことになるものと考えられることから， 塗装材料メ一カ一, 塗装機器メ一カー, 塗装 業者など 3 者が積極姿勢をもって協調し，塗 装のシステムを確立する推進体制に入ること が，今後の業界の課題ではなかろらか。 